\title{
Interaction of Policy Actors in Online Learning Implementation
}

\author{
Intan Puspita Anggraeny ${ }^{1}$, Mas Roro Lilik Ekowanti ${ }^{2}$, M. Husni Tamrin ${ }^{3}$ \\ ${ }^{1}$ Department of Public Administration, Hang Tuah University, Surabaya, Indonesia \\ ${ }^{2}$ Department of Public Administration, Hang Tuah University, Surabaya, Indonesia \\ ${ }^{3}$ Department of Public Administration, Hang Tuah University, Surabaya, Indonesia \\ Corresponding Author: m.husnitamrin@hangtuah.ac.id \\ doi) https://doi.org/10.18196/jgpp.v8i3.11715
}

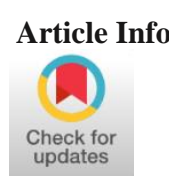

Article History;

Received:

2021-05-06

Revised:

2021-07-12

Accepted:

2021-09-04

\begin{abstract}
This study aims to explain and describe the interaction of policy actors in the implementation of online learning. This study uses a qualitative research method with a descriptive case study approach. Data collection techniques in this study are through observation, documentation, and interviews. The instruments in this study were: a) the researcher himself, b) interview guidelines, c) supporting tools in the form of books, pens, and d) related documents. The results showed that actor interaction can occur if there is communication between implementing actors. Communication in the implementation of online learning can be seen in the accuracy or accuracy of communication and consistency of communication regarding online learning information from the principal to the teacher and finally to students and parents. Interaction between actors, namely principals, teachers, students, and parents in the implementation of online learning has not been carried out effectively. This is because the interaction between implementing actors is unresponsive to one party, namely students and parents. Apart from that, giving complicated and difficult assignments by the teacher, which makes it difficult for students and parents to understand, is also a factor in the existence of negligence or delay.
\end{abstract}

Keyword: Interaction of actors; Policy of Education; Online Learning; Covid-19.

\section{INTRODUCTION}

The Covid-19 pandemic that occurred in Indonesia not only shook the economic and social sectors but also the education sector. The rapid spread of the virus through direct contact has led the government to issue various policies and initiatives to deal with obstacles during the pandemic to reduce the spread of Covid-19 (Akhmad, 2020). Online education policies, especially on the online learning system amid the Covid-19, have become one of the main focuses of almost all levels of society. This sudden policy decision may be a challenge for teachers, students, and parents in its implementation (Dhahir, 2020). Education is one of the main areas of concern, especially in efforts to develop the quality of human resources so that they can play a competent role and contribute to development. The government itself has guaranteed the right of every citizen to get an education, this is stated in the 1945 Constitution Article 31 Paragraph 1 and 2 which states that:

"1) Every citizen has the right to education, 2) every citizen is obliged to attend basic education, and the government is obliged to pay for it."

Education in Indonesia is formulated by the UUD in the preamble to the 1945 Constitution, and its main content is "the intellectual life of the nation." Law number 20 of 2003 concerning the National Educational System article 1 paragraph 1, states as follows: 
"Education is a conscious and planned effort to create an atmosphere of learning and the learning process so that students actively develop their potential...."

Learning is understood as an educational process in schools as official educational institutions. Schools are strategic institutions, most importantly in educating and preparing quality human resources to maintain the previous generation of the relay. However, the learning process in schools at this time cannot be enforced due to the Covid-19 pandemic (Corona Virus Disease 2019) which is spreading in Indonesia. Covid-19 is a disease caused by the severe acute respiratory syndrome coronavirus 2 (SARS-CoV2) virus. Covid-19 can cause respiratory system problems, from mild indications such as flu to lung inflammation, a kind of pneumonia (Pane, 2020).

The number of confirmed cases that are increasing with the distribution of cases that are getting wider certainly forces the government to make policies related to the ongoing conditions. One of the policies made by the Head of The Surabaya City Education Office is Circular Number 800/10308/436.7.1/2020 concerning the Implementation of Learning in the Corona Virus Disease 2019 (Covid-19) Pandemic Condition with a New Normal Order which aims to reduce the spread of Covid-19 in the city of Surabaya, this circular letter has two main points that explain about online learning, namely the second and fourth points which explain that:

"(2) Students carry out learning activities through distance/online learning methods ... (4) Learning activities by teachers/instructors/tutors from the office/workplace are carried out ... virtually adapted to the availability of online devices".

All levels of education, from early childhood education to elementary, junior high school, high school, or vocational high school, including these colleges, apply a homeschooling policy. This matter also triggers the implementation of the work from home (WFH) policy. So that schools and campuses implement online learning nationally. This fact has caused the Covid-19 pandemic to have a serious impact on the education sector globally (Hasanah et al., 2020).

In Indonesia, the online education policy has been implemented since April 2020. The Ministry of Education and Culture of the Republic of Indonesia has ordered all schools in Indonesian territory to conduct online or distance learning by utilizing several supporting platforms such as WhatsApp, google classroom, google meet, and zoom. The Indonesian government also provides a learning channel through a television platform that is accessed free of charge by the internet under the name TV Education (Indonesian Education Television) (Kasih, 2020). In addition, the Ministry of Education and Culture of the Republic of Indonesia also cooperates with a television broadcasting station, namely TVRI. Especially in Surabaya, the Surabaya City Education Office provides facilities through SBO TV broadcasts to help students and teachers to be able to continue to carry out learning online. SBO TV together with the Surabaya City Department of Education created a special program called "SBOTV GURUku" in which several teachers ranging from grades 1 to 6 elementary schools gave presentation material to students. This program runs every Monday to Friday, each class has a different broadcast schedule as well as the material presented. The SBOTV GURUku program can also be accessed via the YouTube platform if you are left behind when watching on television. (Faqih, 2020).

Some of the obstacles experienced by online learning implementers are that students do not have a culture of distance education because so far the learning system has been implemented face-to-face. Online or distance education procedures require time for students to adapt (Purwanto et al., 2020). In addition, some students have to take turns with other family members to use cellphones as a learning tool, which hinders online learning for students. Parents also find it difficult to accompany their children during online learning because some parents work late into the night. Not all parents are trained in internet technology or social media as online education support facilities. Many parents and students admit that they have difficulty mastering subjects (Wijayanto, 2020). Teachers also feel the impact, on average experience difficulties in delivering material, teachers are worried that the modules given cannot be understood by students well.

Previous research conducted during the suspension of COVID-19 classes indicated that parents would report higher levels of stress if they experienced more difficulty supporting their child's learning than before the pandemic (Spinelli et al., 2020). Researchers found that compared 
to caregivers of middle and high school students, caregivers of elementary school students were found to prefer face-to-face rather than in-school or virtual hybrid teaching. These findings provide further evidence that having younger children at home can be stressful and that online learning can be perceived as a challenge for families of younger children. Since parents are generally not prepared or trained to support their children's online learning (Dong et al., 2020), they may experience increased levels of stress and feelings of dissatisfaction with their children's online learning and prefer traditional face-to-face teaching. This of course is also one of the factors that causes the interaction between parents and students to be less good.

Previous research has also shown that teachers feel that although online classes are convenient, can be taken from the comfort of their homes, saving travel time, they appear to be ineffective when compared to classroom methods. Disconnected teacher-student relationship, lack of interaction, inability to involve the group, technical problems were found to be the main problems. Teachers feel that online classes are not as safe and secure as a medium. Some of them even feel that a lack of computer skills hinders the effective use of online teaching platforms. Lack of student interest and involvement was reported by most of the teachers. They reported that during online classes, the main problem they faced was that students made many excuses for not being able to attend classes, for example, network problems, disconnection of connectivity, poor audio and video quality, etc. and it is difficult for them to know whether they are giving a genuine excuse or simply running away from attending class (Nambiar, 2020). This of course is also one of the factors that causes the interaction between teachers and students to be less good.

Previous research has shown that parents who are satisfied with the learning opportunities and engagement provided by the school have lower parenting stress and higher parental involvement (Lau \& Ng, 2019). Conversely, when parents feel that the school is unsupportive and unresponsive to the child's needs in teaching and cooperating with parents, parents experience a loss of need or desire to cooperate which manifests in dissatisfaction (Griffith, 2020). Parental dissatisfaction can in turn increase their likelihood of negatively assessing adjustment events and errors. This, in turn, leads to ineffective parental involvement and problematic child outcomes (Gerstein et al., 2009). This of course is also one of the factors that causes the interaction between parents and the school, especially teachers, to be less good.

The interactions that exist between teachers, students, and parents are still a challenge in implementing online learning. Parents are accustomed to entrusting their children to teachers at school. So that when online learning takes place, where parents are one of the parties who have full control over their children's learning activities, they cannot responsively help their children. So, support and cooperation between parents in the learning process are needed so that it can run successfully. Communication and interaction between teachers, schools, and parents are also expected to run smoothly. Some of the above has drawn attention to be discussed in more depth the interaction actor policies in the implementation of online learning, as the purpose of this study is to shortly explain and describe the interaction of actor policy in the implementation of online learning.

\section{Actor Interaction}

A study of who participates in a policy, for Anderson, Lindblom, and other scientists (Winarno, 2014), the classification of actors in the policy of formal actors or policy actors who have legal authority - such as government agents (bureaucracy), executive leadership, legislative, judiciary and administrator: As well as informal actors or policy actors who participate in the policy process - such as interest groups, political parties, and society.

Actors in policy ensure the system and policy allocation in the process of interaction and kinship (interrelation) which leads to resistance or conflict which is inversely proportional to the nature of harmony. Interaction that exists in the usual form of cooperation or it can be even ber dispute or antagonism (competition)(Madani, 2011).

\section{Online Learning}

An Online learning policy is a policy that manages the education sector starting from the learning system and educational curriculum implemented online (in the net) or online which means it can be done remotely. Online learning policies can occur if there is a standard technology 
platform (such as the internet), which bridges the digital divide, accommodates various languages and cultures, standard curriculum, and evaluation process (Palvia et al., 2018).

Distance Learning is conceptually the same as face-to-face learning, is a systematic and planned learning process to realize the educational norm of character and mentality better students, useful both academically and practically. The difference between distance learning and face-to-face learning only lies in the means or means to achieve it, but the teaching objectives are the same, this can be seen from the learning system that minimizes face-to-face planning and organizing learning and uses more media technology, communication, and information for learning models (Aripin, 2015).

\section{RESEARCH METHOD}

This study uses a qualitative research method with a descriptive case study approach. The case study is understood as a qualitative approach that is expected to explore certain cases in more detail by accumulating various sources of data or information. The form of case studies can be descriptive, exploratory, and explanatory. Descriptive case studies are designed to describe an indication, reality, or ongoing reality (Raco, 2010).

The researcher chose this approach because this study aims to explain and describe the problems related to the interaction of policy actors in the implementation of online learning. This research also requires in-depth analysis to obtain clearer and more meaningful data. In other words, the researcher hopes to study the data in depth.

The selection of informants was carried out using purposive sampling and snowball sampling techniques. Research subjects or informants of this study are: a) teachers, b) parents, c) students, and d) principals. Data collection techniques in this study are through observation, documentation, and interviews. Based on the data collection techniques used, the instruments in this study were: a) the researcher himself, b) interview guidelines, c) supporting tools in the form of books, pens or recorders or recording devices, and d) related documents. This research was conducted using four stages, namely, data collection, data condensation, data presentation, and concluding.

\section{RESULT AND DICUSSION}

An online learning policy is a policy that manages the education sector starting from the learning system and educational curriculum implemented online (in the net) or online which means it can be done remotely. Online learning policies can occur if there is a standard technology platform (such as the internet), which bridges the digital divide, accommodates various languages and cultures, standard curriculum, and evaluation process (Palvia et al., 2018).

Since 2020, extreme changes in education have begun to face revolutionary changes. The government runs social distancing to stem the circulation of the Covid-19 outbreak so that the number of conferences is limited, one of which is in the field of education. This results in teaching and learning activities of learning institutions that were initially face-to-face in the classroom, then transferred to online or distance learning through an online learning system (Sari et al., 2020)

Distance Learning is conceptually the same as face-to-face learning, is a systematic and planned learning process to realize the educational norm of character and mentality better students, useful both academically and practically. The difference between distance learning and face-to-face learning only lies in the means or means to achieve it, but the teaching objectives are the same, this can be seen from the learning system that minimizes face-to-face planning and organizing learning and uses more media technology, communication, and information for learning models (Aripin, 2015).

Cecep Kustandi (in Arifin et al., 2020) suggested that distance learning can also be called elearning. Where learning is not always a class in school as a learning delivery space. But they can use any media, such as school gardens, fields, even in their homes. Then Horton in E-Learning by Design (Cecep Kustandi in (M. Arifin et al., 2020)) argues that e-learning is the use of information technology and computers to produce learning experiences. 
Dermawan (in Arifin et al., 2020) stated that e-learning is a method of teaching. E-Learning is a pillar and a rational result of the development of information and communication technology. Through e-learning, students do not have to be present in class to listen to material from the teacher. E-learning can also shorten the target learning time, which of course saves costs that must be incurred by a study program or education.

The online education policy during the corona pandemic was previously regulated in the Ministry of Education and Culture Circular Number 4 of 2020 concerning the Implementation of Education Policies in the Emergency of the Spread of Corona Virus Disease (Covid-19). The purpose of implementing this online education policy is of course to support government programs, namely, to reduce the spread of Covid-19 so that the number of confirmed cases of Covid-19 can be reduced. In addition, it is stated in the Minister of Education and Culture Circular Letter Number 4 of 2020, the second paragraph as follows:

a) Schools activities are carried out at home via online or distance learning which is carried out to practice a useful learning experience for students, without being burdened by the pressure to complete all curriculum ranges for grade promotion and graduation;

b) Learning activities carried out at home can focus on learning about life skills, including about the Covid-19 pandemic;

c) Activities and learning assignments at home can vary between student, according to the attention and situation of each students, including thinking about the inequality of access/learning facilities at home;

d) Facts or products of home learning activities are submitted in the form of qualitative and useful responses from the teacher, without being required to pass a quantitative score.

The target of this online education policy is of course all levels of society, especially in the field of education such as educators, workers or staff at schools, students and student guardians, or parents of students. Of course, everyone hopes that this online education policy can be implemented properly without any obstacles. Information related to the implementation of this online education policy is conveyed through mass media, such as newspapers, television, radio, and broadcasting services on chat platforms.

Online education policy mechanisms during the corona pandemic are the Kemendikbud Republic of Indonesia instructed all schools in Indonesia to use some of the supporting platforms such as WhatsApp, Google Classroom, Google Meet, and Zoom to carry out online or distance learning. The Indonesian government also provides a learning channel through a TV platform that can be accessed via the internet, namely Educational TV. Furthermore, the Ministry of Education and Culture of the Republic of Indonesia also collaborates with one of the television broadcasting stations, namely TVRI.

A study of who participates in a policy, for Anderson, Lindblom, and other scientists (Winarno, 2014), the classification of actors in policy of formal actors or the policy actors who have legal authority - such as government agents (bureaucracy), executive leadership, legislative, judiciary and administrator: As well as informal actors or policy actors who participate in the policy process - such as interest groups, political parties, and society.

Actors in policy ensure the system and policy allocation in the process of interaction and kinship (interrelation) which leads to resistance or conflict which is inversely proportional to the nature of harmony. Interaction that exists in the usual form of cooperation or it can be even ber dispute or antagonism (competition)(Madani, 2011).

From the explanation above, it can be seen that the implementing actors of the online learning policy are the principal, teachers, students, and parents. The principal is tasked with creating various innovations that can be developed in schools, implementing and designing schools well, and making appropriate strategies so that schools can provide conducive teaching and learning conditions. The teacher is tasked with preparing tools for teaching and learning activities, carrying out teaching and learning activities, carrying out learning process assessment activities, compiling and carrying out corrective and enrichment plans, taking notes on student grades and attendance, and keeping minutes of student learning outcomes Students served to identify and observe the given module, perform the duties of teachers, implement school rules. 
Meanwhile, parents themselves are tasked with assisting their children in the process of learning activities, controlling children's learning activities, meeting children's learning needs.

Paying attention to the duties of the principal, teachers, students, and parents, they are actors of policy implementers who are obliged and responsible for implementing online learning. Their position is very significant because success is very likely to be achieved if the rules, procedures, and work mechanisms associated with humans are interrelated and contribute to the achievement of organizational goals and strategic objectives. This means that the interaction between actors should be effective if the rules, procedures, and working mechanisms are done correctly. In essence, the interactions of the executing actors represent a mutually fulfilling bond. The executing actor as the subject, and the interaction as the process. The interaction of implementing actors on the other hand is a close bond in carrying out their functions, and of course, it cannot be separated from their respective positions and responsibilities (Jamaluddin, 2020).

Launching the Van Meter Van Horn concept, which states that one of the variables that affect implementation performance is communication between organizations and activities. It means that implementers or implementers in a program plan need to find support, cooperation, and coordination with other work units so that coordination and cooperation between institutions are needed for the success of a program. Based on the thought of Van Meter Van Horn, it is identical to the context of interaction between actors. If the communication between organizations and the context of activities is in the institution, then the context of actor interaction is in the individual executing (Jamaluddin, 2020). Actor interaction can occur if there is communication between implementing actors. Communication is an important condition for the occurrence of an interaction.

The implementation of a policy should run efficiently and effectively if the policy can be understood by the responsible implementing actors. That way, it is very meaningful to be able to pay great attention to the accuracy or accuracy of communication with implementing actors, and the consistency or stability of the policies implemented. According to Van Meter Van Horn, the perspective on effective implementation is determined by the accuracy and consistency in communicating a program or policy. The better the organization between the parties involved in the implementation process, the fewer mistakes will be made. And, vice versa.

The implementation of online learning that has been implemented for almost a year since it was implemented in 2020, of course, requires good communication between school principals, teachers, students, and parents due to long distances and not allowing students, parents, and schools to be able to meet face to face. Communication in the implementation of online learning can be seen in the accuracy or accuracy of communication from the principal to the teacher regarding online learning information and finally to students and parents. The school together with the principal and teachers is required to provide an understanding of online learning to students and parents. Information about online learning must also be provided in detail to students and parents so that it does not cause misunderstandings that will hinder the implementation of online learning.

Consistency in communication in providing information about online learning is also very important. The school, namely the principal and teachers, are required to be able to continue to provide information related to the ongoing implementation of online learning. If there is additional information about online learning from the government or the education office, teachers should be able to communicate this directly to students and especially parents. So that parents can immediately prepare and meet the learning needs of their children.

Schools such as teachers and school principals as authorities actively provide technical instructions to students and parents regarding the implementation of online learning such as learning media, learning materials, the timing of teaching and learning activities, attendance, and assignments. The working relationship from the school to students and parents can be said to be a directive working relationship in which the school has the authority and obligation to guide online learning, while on the other hand, students and parents must carry out guidance, directions, considerations, and suggestions given by the school. However, in practice, students and parents 
have not fully fulfilled their obligations, which has resulted in a lack of cooperative interaction between teachers, students, and parents.

According to the author's observations and based on information, the school as the principal and teacher plays a major role in providing direction regarding the implementation of online learning to students and parents in every teaching and learning activity, including for example reminding attendance or assignments to students and parents. However, in practice, some students and parents are negligent in this regard.

The compensation is given by the teachers regarding the implementation of online learning in the material video call activity, or the collection of attendance and assignments has been maximal. Some teachers even provide a limit for collecting attendance or assignments for up to a week after giving assignments, but there are still some students who do not do this. When the teacher tried to contact the students' parents to remind them about this, some parents did not give a good response, and some did not respond at all.

Parents who responded explained that there was negligence or delay in absences or assignments due to lack of quotas or lack of availability of facilities such as cellphones for their children. This can happen to families with middle to lower economic levels, as well as families with more than four members. Besides, lack of insight into the knowledge possessed by the parents also becomes one of the factors that hinder the implementation of online learning. The higher the level of parental education, it is expected that it can direct the child in teaching and learning activities, as well as adjusting the learning style of the child so that it can foster student learning attention. Meanwhile, parents who do not respond become one of the inhibiting factors for teachers to be able to carry out online learning due to negligence or delays in students.

In other conditions, teachers also sometimes give assignments that are complicated or difficult to understand for students and parents with limited facilities. In online learning where this distance learning activity, teachers should also be able to provide material and assignments that are easy for students to understand. So that students can absorb the material provided by the teacher and can immediately carry out their duties. The timing of teaching and learning activities in online learning does not need to be too long, because long-term use of technology certainly has an impact on the health of these students.

The teachers stated that the lack of student involvement in the classroom during online learning was one of the problems with the lack of interaction. They stated that students during online classes made a lot of excuses and showed a lack of seriousness. This in turn tends to make teachers feel demotivated. Followed by a lack of motivation on the part of students to attend classes is another problem faced. The online learning system is more time consuming as it requires them to prepare ppt and additional materials for class. Difficulties in assessing the clarity of concepts by students and to find out whether they understand what is being taught, as well as the inability to monitor and control student behavior, are other problems experienced (Nambiar, 2020).

Meanwhile, students generally prefer face-to-face learning in class to learning at home with online learning because it is easier to understand the material when the teacher explains it directly (face to face). In the classroom, they can interact and learn together (Megawanti et al., 2020). Studying at home is constrained by the limited internet quota (Arifin, 2020). Students want twoway interaction which is sometimes difficult to implement. The learning process cannot reach its full potential until students practice what they learn. Sometimes, online content is all theoretical and doesn't allow students to practice and study effectively. Mediocre course content is also a major problem. Students feel that lack of community, technical problems, and difficulties in understanding instructional objectives are the main barriers to online learning (Song et al., 2004).

Interaction in a class is very important for teachers and students, students learn in class related to their interactions with teachers. Active interactions between teachers and students will create positive relationships in the classroom and contribute to effective learning. In fact, effective teachers can assess changes in student behavior and understand the needs of students in the classroom. In other words, the interaction between students and their teachers is a new direction in communication that occurs in the classroom (Fatimah, 2017). 
For parents in terms of online learning, namely the relationship and communication (social aspects) of parents and children, as well as between parents and teachers. Parents find it difficult to balance their time between daily work and mentoring children's learning activities at home and complain about the complexity of carrying out the teacher's role at home (Lase et al., 2020). The lack of involvement of parents and families to support children's distance learning activities at home is mainly due to the limited time and ability of parents to assist children in learning. These two economic and social factors often become serious obstacles and challenges for the implementation of education. Parents are busy working in various professions and types of work to earn income to cover the costs of meeting family needs, so they do not have enough time to accompany their children to study. On the other hand, parental education also has an impact on the frequency of children's involvement in academic activities. Children in highly educated families are more often involved in structured academic activities such as worksheets, online school resources, and other educational resources during a pandemic (Greenlee \& Reid, 2020).

The interaction between parents and children as students and teachers in schools plays an important role in creating effective and efficient online learning. Parents as a bridge between teachers and students are expected to contribute to the implementation of this policy. The existence of active interactions between parents and children as students and teachers in schools will also foster student learning motivation so that it has a good impact on student outcomes.

So dominant is the active position of the school that is the teacher in the implementation of online learning is inseparable from the authority attached to the position of a teacher. When viewed from the source of the policy, then the authority of the teacher, called the delegation of authority, where the delegation of authority from the government to the organs of other government organs. It's just that this authority in the implementation of online learning is sometimes not followed by real action from other parties, namely students and parents so that the implementation of online learning cannot run optimally. Given the position of the school in this matter of teachers and school principals, the activities carried out by students and parents should be able to participate in supporting the success of implementing online learning.. There is positive interaction in the form of cooperation between teachers, parents, and students, of course, it will be one of the factors in the implementation of this online learning that takes place conducive.

Every factor of institutional members will not be able to work properly if it is not supported by a solid network, after that a solid network, if there is support from working relationships that have mutual understanding and shared views, there will be no conflict of thought patterns. or action (Makmur, 2015). Cooperation is a coordinated effort between groups or citizens that is shown to achieve common goals. The understanding that there are common interests and the existence of an organization is an important fact in cooperation (Kartini, 2014). This means that the cooperation carried out among policy implementers is an important aspect in the success of implementing online learning. Thus the effective interaction and cooperation of implementing actors shall be based on an understanding of the collective of the parties participating in the surrounding environment to reach common interests, namely the success of implementing online learning.

\section{CONCLUSION}

Actor interaction can occur if there is communication between implementing actors. Communication is an important condition for the occurrence of an interaction. Communication in the implementation of online learning can be seen in the accuracy or accuracy of communication and consistency of communication from the principal, then to the teacher regarding online learning information, and finally to students and parents. Interaction between actors that principals, teachers, students and parents in the implementation of learning online are not implemented effectively. This is due, in the interaction between actors' implementers are not responsive to one side namely students and parents in which it would be able to inhibit 
implementation of teaching and learning activities compiled by the teachers. Apart from that, the assignment of complicated and difficult assignments by the teacher, which makes it difficult for students and parents to understand, is also a factor in the existence of negligence or delay.

Based on the conclusions from the research results that have been described to make the interaction of policy actors more effective in the implementation of online learning, the authors provide suggestions, namely: It is necessary to develop a pattern of teamwork that is jointly oriented based on collective awareness and responsibility. Build collaboration between stakeholders (teachers, students, and parents). Teachers and parents can help each other in arousing student motivation so that teaching and learning activities can be carried out optimally. Schools should implement learning hours that are not too long. Teachers should be more flexible in teaching and learning activities, including when giving assignments.

\section{ACKNOWLEDGEMENT}

The author wishes to express his deepest gratitude to Prof. Dr. Mas Roro Lilik Ekowanti, MS from the Public Administration Study Program, Hang Tuah University for giving her time, and attention and guidance in completing this research. Mr. M. Husni Tamrin, S.AP., M.KP from the Public Administration Study Program, Hangtuah University for giving his time, and attention and guidance in completing this research.

\section{REFERENCE}

Akhmad, H. T. (2020). Mendikbud Pastikan Kebijakan Pembelajaran di Masa Pandemi Covid-19 Terlaksana. Okenews. https://news.okezone.com/read/2020/09/03/65/2271791/mendikbud-pastikankebijakan-pembelajaran-di-masa-pandemi-covid-19-terlaksana

Arifin, H. N. (2020). Respon Siswa Terhadap Pembelajaran Dalam Jaringan Masa Pandemi Chovid19 Di Madrasah Aliyah Al-Amin Tabanan. Widya Balina, 53(9), 1689-1699.

Arifin, M., Hartati, L., Silaen, V., \& Yusoh, A. (2020). Manajemen pembelajaran pendidikan jarak jauh untuk millenial. In Kumpulan Penelitian dan Pengabdian Dosen. Haura.

Aripin, S. (2015). Kebijakan pendidikan jarak jauh. Seminar Nasional Riset Inovatif, 3, 380-385.

Dhahir, D. F. (2020). a Qualitative Study on Students Behavior Toward Sudden Online Learning Policy. Journal of Information Technology and Its Utilization, 3(1), 18. https://doi.org/10.30818/jitu.3.1.3111

Dong, C., Cao, S., \& Li, H. (2020). Young children's online learning during COVID-19 pandemic: Chinese parents' beliefs and attitudes. Children and Youth Services Review, 118(September), 105440. https://doi.org/10.1016/j.childyouth.2020.105440

Faqih, A. (2020). Link Live Streaming GURUku di SBO TV SD Kelas 1, 2, 3, 4, 5, 6 Senin 5 Oktober 2020: Persamaan Kata Artikel ini telah tayang di surya.co.id dengan judul Link Live Streaming GURUku di SBO TV SD Kelas 1, 2, 3, 4, 5, 6 Senin 5 Oktober 2020: Persamaan Kata. Surya.Co.Id. https://surabaya.tribunnews.com/2020/10/04/link-live-streaming-gurukudi-sbo-tv-sd-kelas-1-2-3-4-5-6-senin-5-oktober-2020-persamaan-kata

Fatimah, G. S. (2017). an Analysis of Fillers Used By Lecturer and Students in Efl Classroom Interaction. JALL (Journal of Applied Linguistics and Literacy), 1(2), 43. https://doi.org/10.25157/jall.v1i2.1735

Gerstein, E. D., Crnic, K. A., Blacher, J., \& Baker, B. L. (2009). Resilience and the course of daily parenting stress in families of young children with intellectual disabilities. Journal of Intellectual Disability Research, 53(12), 981-997. https://doi.org/10.1111/j.1365-

192 | Intan Puspita Anggraeny ${ }^{1}$, Mas Roro Lilik Ekowanti ${ }^{2}$, M. Husni Tamrin ${ }^{3}$ 


\subsubsection{0.x}

Greenlee, E., \& Reid, A. (2020). Parents supporting learning at home during the COVID-19 pandemic. Statistics Canada, 45280001, 1-9.

Griffith, A. K. (2020). Parental Burnout and Child Maltreatment During the COVID-19 Pandemic. Journal of Family Violence, June. https://doi.org/10.1007/s10896-020-00172-2

Hasanah, A., Sri Lestari, A., Rahman, A. Y., \& Danil, Y. I. (2020). Analisis Aktivitas Belajar Daring Mahasiswa Pada Pandemi COVID-19. Karya Tulis Ilmiah (KTI) Masa Work From Home (WFH) Covid-19 UIN Sunan Gunung Djati Bandung Tahun 2020, 4-8. http://digilib.uinsgd.ac.id/id/eprint/30565

Jamaluddin, Y. (2020). Interaksi Aktor Dalam Pelaksanaan Kebijakan Pemerintah Daerah Terkait Penggunaan Dana. Ilmu Administrasi Publik Dan Pembangunan, 1(20217), 1-12. http://ppjp.ulm.ac.id/journals/index.php/jpp/article/view/2450/2007

Kartini. (2014). Kerjasama Petani Dalam Pengelolaan sumberdaya Air Berkelanjutan Di Desa Sedahan Jaya Kec. Sukadana Kab. Kayong Utara Provinsi Kalmantan Barat.

Kasih, A. P. (2020). Kemendikbud Sajikan TV Edukasi untuk PAUD hingga SMA, Ini Jadwalnya. Kompas.Com. https://www.kompas.com/edu/read/2020/04/06/102414671/kemendikbud-sajikan-tvedukasi-untuk-paud-hingga-sma-ini-jadwalnya

Lase, D., Zaluchu, S. E., Daeli, D. O., \& Ndraha, A. (2020). Parents' Perceptions of Distance Learning during Covid-19 Pandemic in Rural Indonesia. December. https://doi.org/10.35542/osf.io/hfza7

Lau, E. Y. H., \& Ng, M. L. (2019). Are they ready for home-school partnership? Perspectives of kindergarten principals, teachers and parents. Children and Youth Services Review, 99, 1017. https://doi.org/10.1016/j.childyouth.2019.01.019

Madani, M. (2011). Dimensi Interaksi Aktor Dalam Proses Perumusan Kebijakan Publik. Graha Ilmu.

Makmur. (2015). Efektivitas Kebijakan Kelembagaan Pengawasan. Refika Aditama.

Megawanti, P., Megawati, E., \& Nurkhafifah, S. (2020). Persepsi Peserta Didik terhadap PJJ pada Masa Pandemi COVID-19. Jurnal Ilmiah Pendidikan, 7(2), 75-82.

Nambiar, D. (2020). The impact of online learning during COVID-19: students' and teachers' perspective. The International Journal of Indian Psychology, 8(2), 784-793. https://doi.org/10.25215/0802.094

Palvia, S., Aeron, P., Gupta, P., Mahapatra, D., Parida, R., Rosner, R., \& Sindhi, S. (2018). Online Education: Worldwide Status, Challenges, Trends, and Implications. Journal of Global $\begin{array}{llll}\text { Information Technology } & \text { 21(4), } & \text { 233-241. }\end{array}$ https://doi.org/10.1080/1097198X.2018.1542262

Pane, M. D. C. (2020). Covid-19. Alodokter. https://www.alodokter.com/covid-19

Purwanto, A., Pramono, R., Asbari, M., Santoso, P. B., Wijayanti, L. M., Choi, C. H., \& Putri, R. S. (2020). Studi Eksploratif Dampak Pandemi COVID-19 Terhadap Proses Pembelajaran Online di Sekolah Dasar. EduPsyCouns: Journal of Education, Psychology and Counseling, 2(1), 1-12. https://ummaspul.e-journal.id/Edupsycouns/article/view/397

Raco, J. (2010). Metode penelitian kualitatif: jenis, karakteristik dan keunggulannya. PT Grasindo. https://doi.org/10.31219/osf.io/mfzuj

Sari, W., Rifki, A. M., \& Karmila, M. (2020). Analisa Kebijakan Pendidikan Terkait Implementasi Pembelajaran Jarak Jauh Pada Masa Darurat Covid 19. Jurnal MAPPESONA, 1, 12. 
Song, L., Singleton, E. S., Hill, J. R., \& Koh, M. H. (2004). Improving online learning: Student perceptions of useful and challenging characteristics. Internet and Higher Education, 7(1), 59-70. https://doi.org/10.1016/j.iheduc.2003.11.003

Spinelli, M., Lionetti, F., Pastore, M., \& Fasolo, M. (2020). Parents' Stress and Children's Psychological Problems in Families Facing the COVID-19 Outbreak in Italy. Frontiers in Psychology, 11(July), 1-7. https://doi.org/10.3389/fpsyg.2020.01713

Wijayanto. (2020). Pembelajaran Daring Tak Maksimal, Guru dan Ortu Tak Siap. Radasr Surabaya. https://radarsurabaya.jawapos.com/read/2020/09/08/212791/pembelajaran-daringtak-maksimal-guru-dan-ortu-tak-siap

Winarno, B. (2014). Teori dan Proses Kebijakan Publik. Media Press. 